\title{
DISEMINASI TEKNOLOGI BUDIDAYA ANGGREK PADA SKALA RUMAH TANGGA DI KELURAHAN LIMAU MANIS PADANG
}

\author{
Mairawita $^{1}$, Muhammad Nazri Janra ${ }^{1 *}$, Henny Herwina ${ }^{1}$ dan Suwirmen ${ }^{1}$ \\ Jurusan Biologi Fakultas Matematika dan Ilmu Pengetahuan Alam Universitas Andalas \\ *) Email: mnjanra@ sci.unand.ac.id
}

\begin{abstract}
ABSTRAK
Tumbuhan anggrek (Orchidaceae) merupakan salah satu kelompok tumbuhan berbunga terbesar yang kurang lebih mempunyai 28.000 jenis dari sekitar 763 genera. Sebagai tumbuhan epifit, anggrek telah lama didomestikasi dan dibudidayakan oleh manusia untuk berbagai keperluan, terutama untuk kepentingan estetika dan keindahan. Anggrek juga menduduki salah satu posisi sebagai tumbuhan yang cukup banyak diperjualbelikan secara komersil. Sayangnya, mengingat cara tumbuh dan kebutuhan hidup yang berbeda dibandingkan dengan tumbuhan hias konvensional lainnya, anggrek cenderung dianggap sebagai tumbuhan yang sulit dibudidayakan. Di lain pihak, walaupun mempunyai kondisi lingkungan yang mendukung untuk melakukan budidaya anggrek, Sumatera Barat tidak pernah benar-benar menjadi penghasil anggrek secara komersil. Untuk itulah, kegiatan penyuluhan mengenai teknik budidaya anggrek yang disertai dengan pemberian motivasi untuk menanam anggrek dilakukan pada mitra kegiatan yaitu kaum ibu dan perempuan di Kelurahan Limau Manis Padang pada tanggal 30 November 2018. Metoda kegiatan ini meliputi pemberian penyuluhan tentang teknik budidaya anggrek, demonstrasi dan evaluasi kegiatan menggunakan tanya jawab dan kuisioner. Dari analisis hasil evaluasi, kegiatan ini memberikan peningkatan pengetahuan dan motivasi dalam melakukan budidaya anggrek. Di samping itu, hasil rangkuman dari kuisioner pada peserta kegiatan memberikan gambaran bahwa metoda presentasi dengan menggunakan slide PowerPoint disertai dengan demonstrasi sepenuhnya mampu menjembatani transfer pengetahuan mengenai teknik budidaya anggrek. Lebih jauh lagi, peserta menyatakan minat yang sangat tinggi untuk membudidayakan anggrek pada skala rumah tangga sembari meminta disertai dengan pembinaan lebih lanjut dan berkala.
\end{abstract}

Kata Kunci: budidaya, epifit, kuisioner, orchidaceae, slide powerpoint

\section{Technology Dissemination of Graphic Culture in Household Scale in Limau Manis Village, Padang}

\begin{abstract}
Orchids (Orchidaceae) is one of the largest group of flowering plants in the world with 28,000 species and 763 genera. As epiphyte plants, orchids have been long domesticated by human and cultured for various benefits, mainly for their aesthetics and decoration aspects. Orchids have also become one of the commercial trading commodities. Unfortunately, considering it unique living condition and needs, differed in many ways with other conventional ornamental plants, made orchids to be thought as a difficult plant to culture. On the other hand, despite having suitable conditions for developing orchids culture, West Sumatra has never become the commercial producer of orchids. Therefore, this knowledge dissemination activity, along with motivational improvement for orchid culture, was conducted onto our partner the household mothers and women in Limau Manis Village Padang on 30 November 2018. Its methodology involved presentation regarding the techniques in culturing orchids, demonstration, and evaluation through discussion and questionnaire. Based on analysis on evaluation result, this activity has improved the knowledge and motivation of culturing orchids among the trainees. Moreover, from the summary drawn from the questionnaire, respondents depict their fully comprehension upon training materials delivered with slide PowerPoint and demonstration, which served as bridge between the trainer and trainees. Furthermore, the trainees expressed their high motivation to culture orchids at household level, while requesting for further regular and technical training regarding the orchid culture.
\end{abstract}

Keywords: culture, epiphyte, Orchidaceae, questionnaire, slide PowerPoint 


\section{PENDAHULUAN}

Anggrek secara umum dapat digolongkan sebagai tumbuhan monokotil yang dapat dibedakan dari jenis tumbuhan monokotil lainnya melalui susunan stamen yang mengelompok pada satu sisi dan terpisah sebagian dengan pistil, biji yang kecil dan berjumlah banyak serta bunganya yang mempunya labellum atau bibir bunga (Dressler 1981). Anggrek umumnya tumbuh sebagai organisme epifit yang menempel kepada substrat atau tumbuhan lainnya dengan menggunakan akar dan batangnya, dimana batang umumnya berbentuk rimpang atau bulbus serta daun yang bertulang sejajar (Dressler 1993). Terdapat sekitar 28.000 jenis anggrek yang telah diidentifikasi di dunia, dimana sebagian besarnya terbagi atas genus Bulbophyllum (2000 jenis), Epidendrum (1500 jenis), Dendrobium (1400 jenis) dan Pleurothalis (1000 jenis) di samping jenis-jenis yang tergolong ke dalam genera Vanda, Phalaenopsis, Cattleya dan Vanilla yang telah lama dibudidayakan (Pillon \& Chase 2007). Di Indonesia sendiri, terdapat kurang lebih 10.000 jenis anggrek, terutama jenis khas tropis yang berpotensi untuk dijadikan tumbuhan hias (Sutiyoso, 2000).

Anggrek telah lama dibudidayakan oleh manusia untuk berbagai kepentingan, terutama sebagai tanaman hias karena nilai keindahan dan estetikanya. Anggrek bulan (Phalaenopsis spp) merupakan komoditas utama pada pertanian anggrek di Amerika dengan nilai devisa yang dihasilkan pada tahun 2000 diperkirakan mencapai 100 juta dollar Amerika (Griesbach, 2002). Anggrek kelompok Dendrobium dianalisis masih dapat memberikan keuntungan yang signifikan walaupun terdapat kenaikan ongkos produksi di Indonesia (Rahman \& Juraemi, 2008). Sedangkan Santosa (2006) menyatakan bahwa budidaya anggrek Vanda di Jawa Tengah, walaupun mengalami fluktuasi, tetapi dianalisis tetap bisa menghasilkan keuntungan sampai 56\% per tahun per hektarnya. Budidaya anggrek sendiri dapat dipadupadankan dengan konsep pelestarian lingkungan, dimana anggrek alam ataupun anggrek silangan dapat ditumbuhkan dalam kawasan lindung ataupun kawasan yang mendapatkan pengaruh aktifitas manusia (Hani, Widyaningsih \& Damayanti, 2014); (Kurniawan et al., 2018).

Terlepas dari semua keuntungan yang ditawarkan dari budidaya anggrek yang telah disebutkan di atas, masih banyak keraguan dari masyarakat untuk melakukannya walaupun dalam skala rumah tangga sekalipun. Masih ada anggapan bahwa anggrek merupakan tumbuhan yang sulit dikembangbiakan, sangat rentan terhadap serangan penyakit dan hama, serta membutuhkan biaya yang cukup besar untuk perawatannya. Untuk itulah, diperlukan usaha yang terus menerus untuk mendorong kegiatan pembudidayaan anggrek di kalangan masyarakat melalui bimbingan dan pelatihan teknis mengenai cara budidaya dan pemasaran anggrek.

Kaum ibu dan perempuan di kawasan Kelurahan Limau Manis merupakan tujuan dari kegiatan mengenai budidaya anggrek ini. Kelurahan Limau Manis merupakan wilayah administratif yang berbatasan dengan kampus Universitas Andalas, sehingga dalam jangka panjang memberikan keuntungan berupa lokasi yang dekat untuk melakukan pembinaan yang intensif. Kaum ibu dan perempuan sendiri dipilih karena menjadi penggerak yang paling tepat untuk usaha budidaya anggrek skala rumah tangga, selain biasanya kelompok masyarakata ini mempunyai waktu luang yang bisa dimanfaatkan di luar mengurus kegiatan rumah tangga sehari-harinya. 


\section{METODA}

Kegiatan ini telah dilakukan kepada kaum ibu dan perempuan di Kelurahan Limau Manis, Padang pada tanggal 30 November 2018 dan bertempat di aula Kantor Kelurahan Limau Manis Padang. Metode ini meliputi kegiatan penyampaian materi teknis budidaya anggrek, demonstrasi sederhana dengan menggunakan ragam tumbuhan anggrek serta diikuti dengan evaluasi terhadap peserta kegiatan.

Penyampaian materi tentang teknis budidaya anggrek menggunakan slide PowerPoint yang telah disiapkan secara ringkas dan menggunakan gambar-gambar yang informatif. Selain itu, pemateri pada kegiatan ini, Dr. Mairawita, merupakan praktisi yang telah melakukan kegiatan budidaya anggrek selama bertahun-tahun serta mengetahui seluk beluk dan ragam hal menyangkut pertumbuhan anggrek. Selain itu, beragam jenis anggrek yang sedang berbunga turut dihadirkan ke dalam ruangan tempat pemberian materi, sehingga membantu dalam memberikan contoh jenis-jenis anggrek yang dibudidayakan, serta memotivasi peserta kegiatan untuk dapat kemudian menerapkannya di rumah masing-masing. Beberapa dari anggrek tersebut kemudian dijadikan sebagai reward sekaligus starter budidaya untuk para peserta yang terpilih saat evaluasi kegiatan dilakukan.

Evaluasi kegiatan ini dilakukan dengan menggunakan media tanya jawab antara pemberi materi/panitia kegiatan dengan peserta kegiatan. Di samping itu, untuk mengetahui tingkat pemahaman peserta, sekaligus untuk mendapatkan masukan terhadap materi penyuluhan yang disampaikan serta harapan mereka untuk kegiatan penyuluhan budidaya anggrek di masa yang akan datang, diberikan kuisioner kepada perwakilan 20 orang peserta (format kuisioner terlampir). Terdapat 6 butir pertanyaan berupa paduan antara pertanyaan terbuka dan tertutup yang kemudian dianalisis dengan statistik sederhana dan diuraikan secara deskriptif.

\section{HASIL DAN PEMBAHASAN}

Pelaksanaan kegiatan ini intinya berada pada kegiatan penyuluhan berupa pemberian materi terkait teknis budidaya anggrek. Di dalam inisiasi kerjasama antara panitia kegiatan penyuluhan dengan pihak Kelurahan Limau Manis, disyaratkan bahwa peserta yang akan diundang adalah yang benar-benar berminat dengan budidaya anggrek. Hal ini bertujuan untuk mengefektifkan pemberian materi dan memudahkan pembinaan lebih lanjut nantinya. Selain itu, ketika pelaksanaan penyuluhan teknis budidaya anggrek, pada ruangan tempat kegiatan juga dihadirkan puluhan anggrek dari beragam jenis yang ditata sedemikian rupa untuk memberikan efek daya tarik kepada peserta kegiatan (Gambar 1). Selain itu, anggrek-anggrek yang dihadirkan juga membantu dalam mengenalkan ciri-ciri fisik dari beragam jenis anggrek yang ada, karena bisa ditunjukkan secara langsung kepada peserta. 


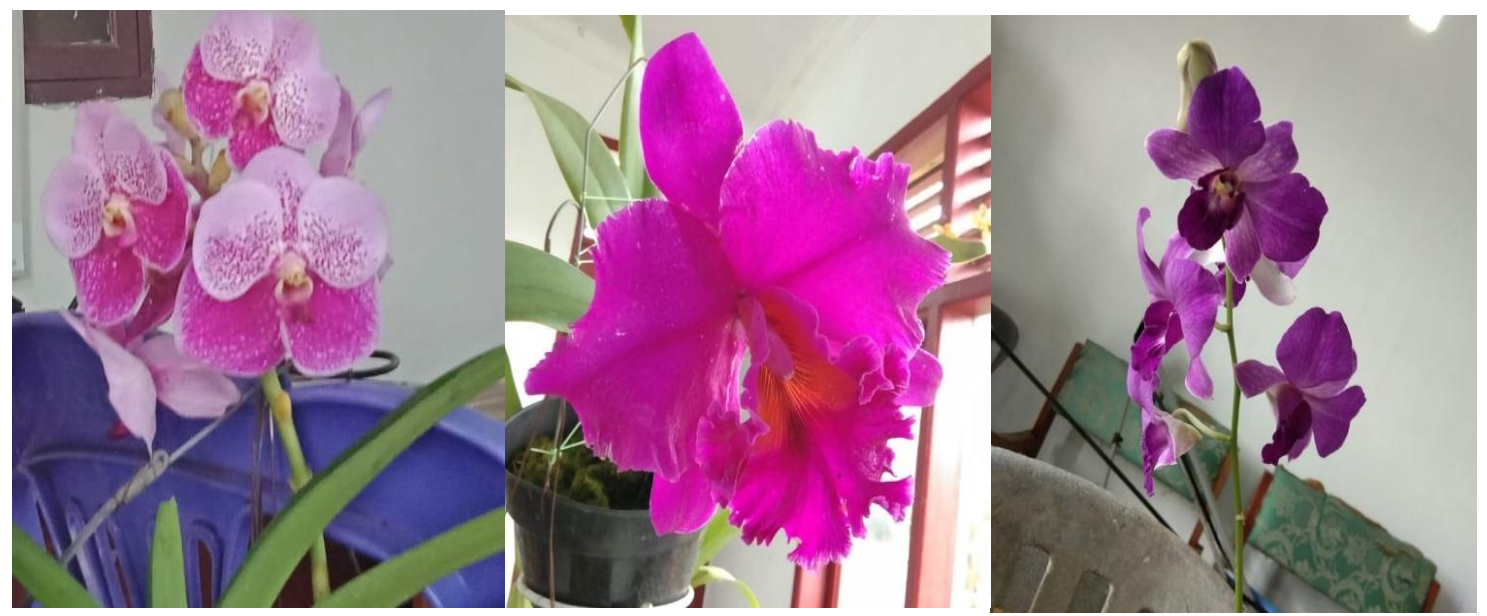

Gambar 1. Beberapa Jenis Anggrek Budidaya. Vanda (Kiri), Cattleya (Tengah), Dendrobium (Kanan)

Materi kegiatan antara lain mencakup tentang ragam jenis berikut ciri-ciri umum anggrek yang banyak dibudidayakan, peran dan fungsi tumbuhan anggrek bagi kehidupan manusia, cara memperoleh bibit anggrek serta cara pemeliharaannya. Untuk cara pemeliharaan, juga dijelaskan tentang medium tumbuh yang digunakan, intensitas cahaya yang dibutuhkan serta intensitas penyiraman. Peserta juga diberikan pengetahuan tentang siklus vegetatif dan generatif pada anggrek yang membutuhkan perbedaan kadar unsur hara yang diberikan di dalam pupuknya, yaitu tinggi unsur Nitrogen $(\mathrm{N})$ untuk masa pembentukan daun (fase vegetatif) dan tinggi unsur Phosphat (P) untuk masa perbungaan (generatif). Juga diterangkan bahwa sebaiknya anggrek yang baru saja selesai berbunga diistirahatkan dalam dua atau lebih fase vegetatif, sebelum siap untuk masuk ke tahap perbungaan kembali. Lebih jauh lagi dijelaskan bahwa pemupukan sebaiknya dilakukan dengan menyemprotkan pupuk dalam bentuk cair ke bagian bawah daun, karena penyerapan unsur hara mencapai 70-80\% dibandingkan dengan pengaplikasian di bagian anggrek yang lainnya.
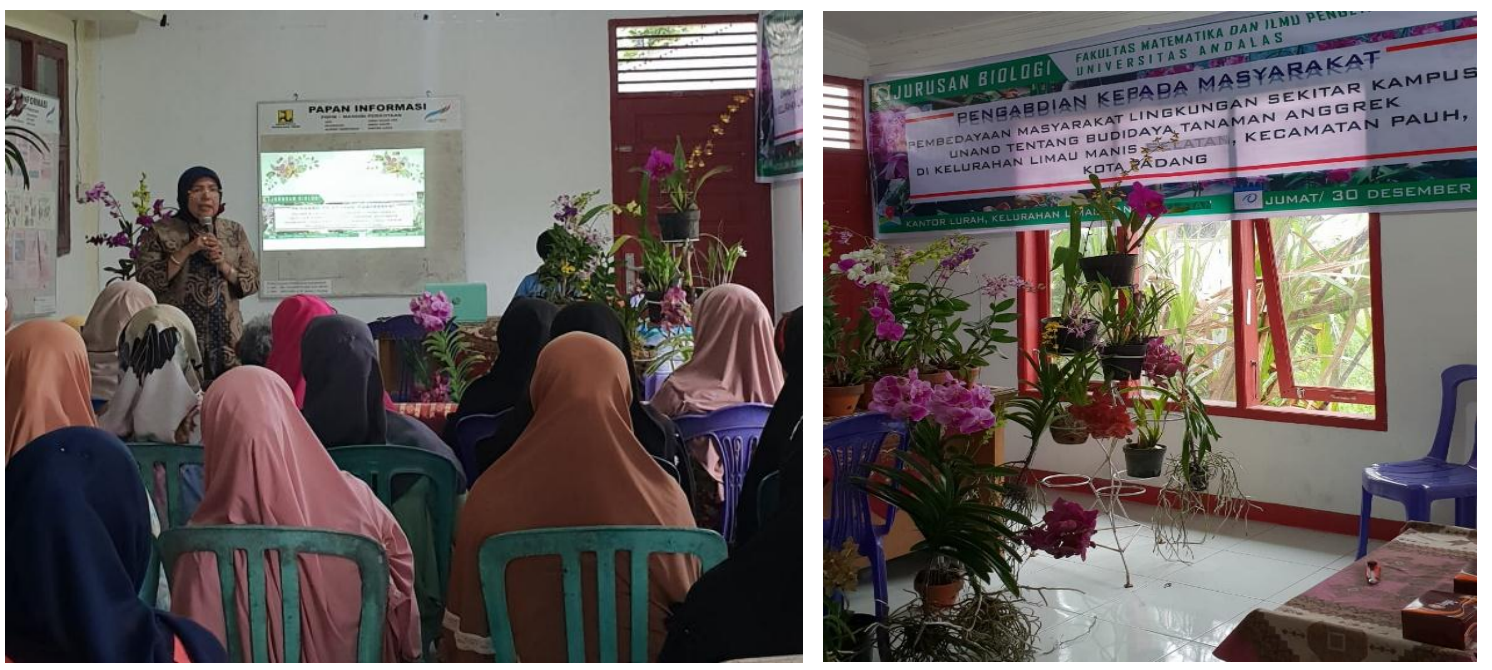

Gambar 2. Penyuluhan Budidaya Anggrek di Ruang Yang Ditata dengan Beragam Anggrek 
Untuk perbanyakan tanaman anggrek, dijelaskan kepada peserta kegiatan bahwa terdapat beberapa cara untuk itu, dimulai dari yang paling sulit dilakukan sampai yang mudah dilaksanakan dalam skala rumah tangga. Teknik kultur jaringan merupakan cara yang cukup sulit untuk dilakukan karena membutuhkan ruang laboratorium, tetapi bibit yang didapatkan sangat banyak dan mempunyai mutu yang seragam. Untuk skala rumah tangga, metode-metode pemisahan rumpun, stek, tunas dari tangkai bunga (khusus untuk anggrek Phalaenopsis), serta perkecambahan serbuk biji dapat dilakukan dengan mudah. Untuk pemisahan rumpun, terutama pada jenis Dendrobium, harus dilakukan dengan kesabaran, karena minimal harus terdapat 4-6 bulbus (batang anggrek) di dalam rumpun sebelum bisa dipisahkan menjadi dua bagian yang sama banyak. Sedangkan metode stek batang, dapat dilakukan pada anggrek yang berbatang lurus dan panjang, seperti Vanda atau anggrek kalajengking Arachnis flos-aeris, dimana batang yang mempunyai akar dipotong pada panjang tertentu dan ditanam langsung pada media. Pada sesi ini juga diterangkan cara merawat dan mengeluarkan bibit anggrek botolan hasil dari kultur jaringan sebelum dipindahkan ke media tanam.

Hal terakhir yang dijelaskan dalam sesi penyuluhan langsung ini adalah tentang pemberantasan hama dan penyakit yang menyerang anggrek. Hama anggrek umumnya berupa hewan invertebrate seperti siput atau serangga yang umumnya memakan bagian tumbuhan yang lunak. Sedangkan penyakit yang menyerang anggrek biasanya ditimbulkan oleh serangan jamur, bakteri atau virus. Untuk bagian ini, dijelaskan penyebab timbulnya serangan berikut cara pendegahannya, tanda-tanda anggrek yang sedang terserang hama dan penyakit, serta cara mengatasinya dengan menggunakan metoda alami dan kimiawi, jika anggrek telah terserang.

Sebagai sebuah kegiatan transfer pengetahuan dengan menggunakan teknik presentasi audiovisual untuk menyampaikan materi penyuluhan yang telah dirancang, maka tindakan evaluasi dilakukan untuk mengetahui sejauh mana pemahaman yang didapatkan oleh peserta kegiatan. Biasanya terdapat tiga tingkat bentuk perubahan yang diharapkan pada peserta transfer pengetahuan yaitu; 1) memperoleh ilmu pengetahuan, 2) perubahan dalam sikap perilaku, dan 3) perubahan dalam praktek kegiatan (Lafreniere et al. 2013). Untuk kegiatan penyuluhan ini, tingkat perubahan yang diharapkan terjadi pada peserta kegiatan paling kurang sampai pada tahapan 1, yaitu memperoleh ilmu pengetahuan baru. Untuk itu, dilakukan sesi tanya jawab, dimana peserta kegiatan diberikan kesempatan terlebih dahulu untuk mengajukan pertanyaan terkait dengan presentasi yang telah diberikan. Selanjutnya, setelah tidak ada lagi peserta yang memberikan pertanyaan, dilakukan sesi kuis, dimana peserta diberikan pertanyaan seputar masalah budidaya anggrek oleh panitia kegiatan. Untuk memberikan semangat dalam kedua sesi evaluasi tersebut, setiap panitia dan peserta yang terlibat diberikan reward berupa anggrek. Bagi peserta, reward berupa anggrek ini sekaligus juga menjadi starter untuk budidaya anggrek lebih lanjut.

Bentuk evaluasi terakhir adalah dengan menggunakan kuisioner yang diberikan kepada 20 orang dari total 27 orang peserta kegiatan. Beberapa keuntungan dari evaluasi dengan menggunakan kuisioner ini adalah diketahuinya informasi demografi dari peserta kegiatan, serta memberikan kesempatan kepada peserta yang mungkin sulit dalam menyampaikan pendapat atau pertanyaan secara lisan. Dari data isian kuisioner, diketahui bahwa usia peserta kegiatan umumnya berada pada rentang usia 41-50 tahun (11 orang), selebihnya berada pada rentang usia 21-30 tahuan dan 31-40 tahun. Hal ini mungkin berkaitan dengan pekerjaan sebagian besar dari peserta kegiatan (15 orang) 
sebagai ibu rumah tangga. Umumnya di rumah tangga di Indonesia, usia produktif ibu rumah tangga adalah antara 20-40 tahun, tetapi kemungkinan pada daerah pedesaan usia produktif ini mungkin lebih lanjut lagi, sehingga makin besar potensi keterlibatan ibu rumah tangga sebagai pelaku budidaya anggrek skala rumah tangga.

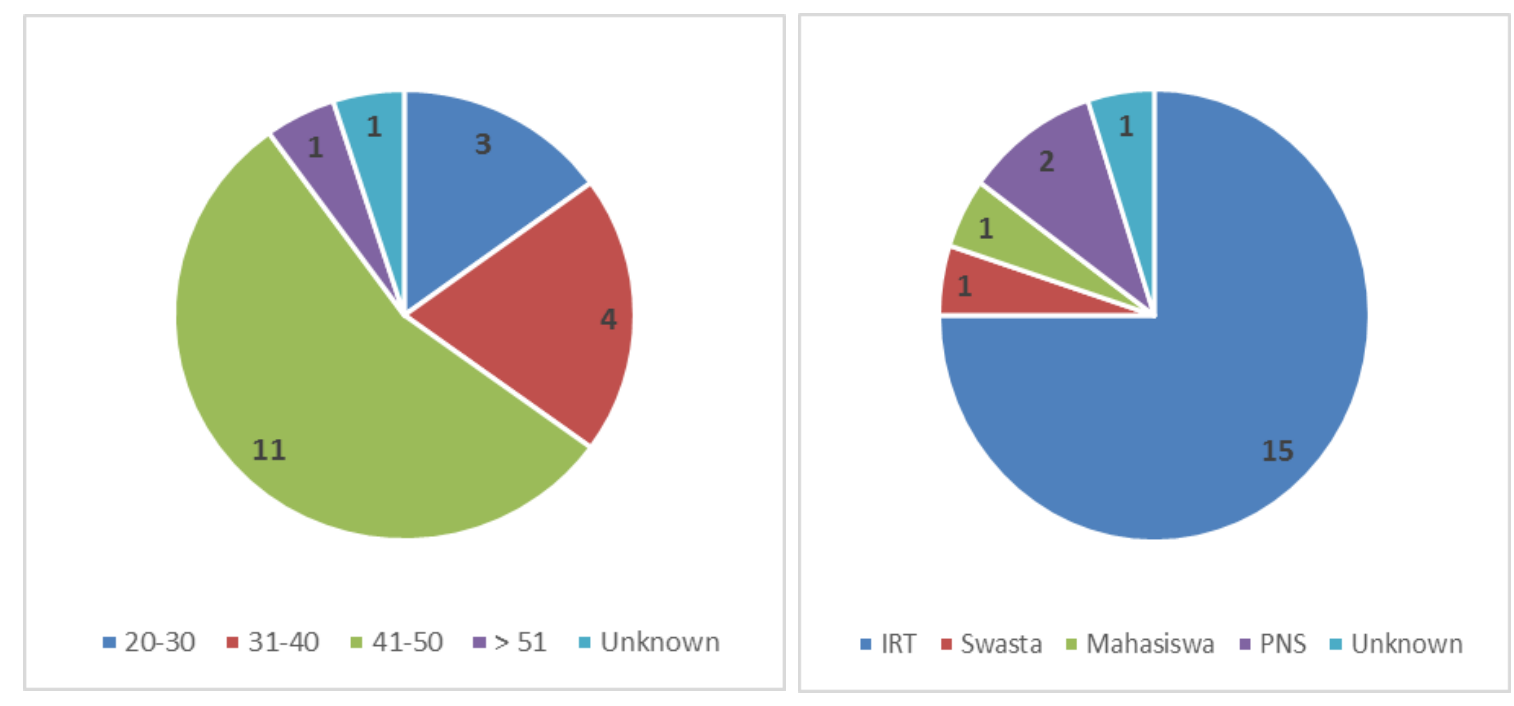

Gambar 3. Usia dan Pekerjaan Peserta Kegiatan Penyuluhan.

Dari serangkaian pertanyaan di dalam kuisioner yang diberikan kepada peserta kegiatan, diketahui bahwa materi yang diberikan melalui slide presentasi PowerPoint serta demonstrasi teknik budidaya anggrek dapat dimengerti secara keseluruhannya. Materi yang dibawakan juga dianggap menarik oleh seluruh peserta (Gambar 4a, b). Walaupun materi teknis budidaya dapat dimengerti secara keseluruhan, tetap terdapat beberapa hal yang harus dijelaskan ulang kepada 6 orang $(30 \%)$ peserta, seperti cara membedakan jenis-jenis anggrek secara morfologis, takaran pupuk yang digunakan serta cara penyilangan anggrek (Gambar 4c). Di akhir kegiatan, seluruh peserta (100\%) kegiatan penyuluhan menyatakan minatnya untuk melakukan budidaya anggrek di rumahnya masing-masing.

Walaupun mendapatkan respons yang sangat positif, peserta kegiatan penyuluhan memberikan beberapa catatan untuk menindaklanjuti kegiatan yang telah dilakukan, ditambah dengan pemberian tumbuhan anggrek pada saat sesi evaluasi kegiatan penyuluhan yang menambah motivasi untuk melakukan kegiatan budidaya. Lebih lanjut, sebanyak tujuh orang peserta kegiatan menekankan perlunya dilakukan kegiatan pembinaan lanjutan berupa bimbingan tentang budidaya, penyilangan dan perbanyakan anggrek. Mereka juga menyarankan bahwa kegiatan yang dilakukan harus dievaluasi secara berkala untuk melihat bagaimana kemajuan yang dilakukan oleh para peserta. Saran pembinaan ini mungkin dapat dilakukan melalui skema kemitraan antara Jurusan Biologi dengan kaum ibu dan perempuan di Kelurahan Limau Manis Padang. 


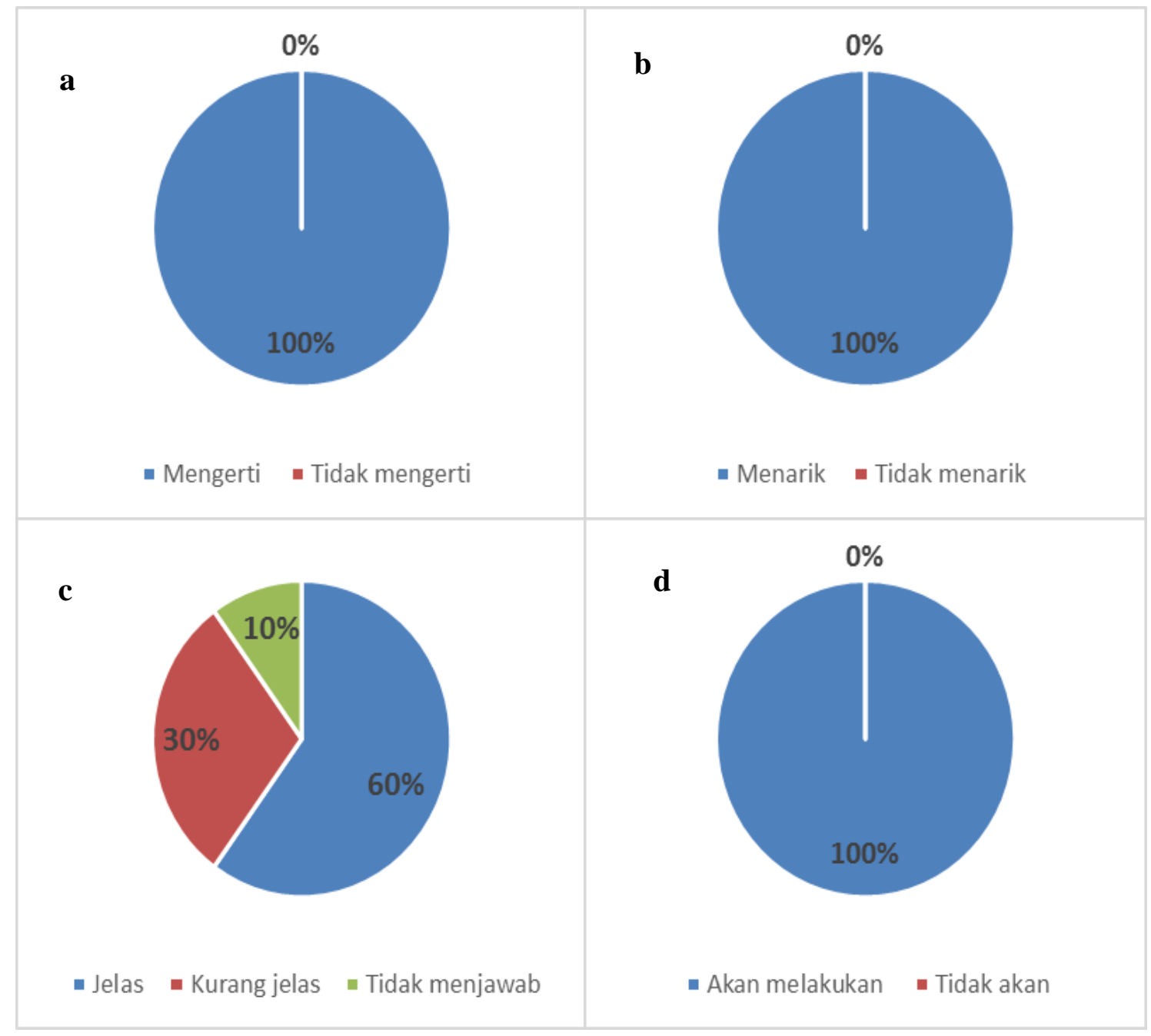

\section{KESIMPULAN DAN SARAN}

Kegiatan ini berupa penyuluhan teknis budidaya anggrek ini memberikan tambahan pengetahuan dan peningkatan motivasi dari kaum ibu dan perempuan di Kelurahan Limau Manis. Kaum ibu dan perempuan di kelurahan ini pada dasarnya mampu melakukan pembudidayaan anggrek secara sederhana, tetapi mereka mengharapkan adanya bimbingan yang diberikan secara teratur terhadap mereka. Analisis terhadap jawaban yang diberikan oleh peserta di dalam evaluasi kegiatan dengan menggunakan kuisioner, diketahui bahwa tindakan transfer pengetahuan yang dilakukan melalui penyuluhan berhasil secara keseluruhan mencapai para peserta kegiatan.

\section{UCAPAN TERIMA KASIH}

Para penulis mengucapkan terima kasih yang sebesar-besarnya kepada Lembaga Penelitian dan Pengabdian Masyarakat (LPPM) Universitas Andalas yang telah memberikan bantuan dana untuk kegiatan pengabdian ini melalui skim IbPSNB 
UNAND dengan nomor kontrak 5/UN.16.17/XIII.PM.IbPSNB/LPPM/2018. Selanjutnya penulis juga berterima kasih kepada Bapak Lurah di Kelurahan Limau Manis Padang beserta jajarannya yang telah menjembatani kegiatan ini. Ucapan yang sama juga diberikan kepada Erizal Mukhtar, Dahelmi, Indra Junaidi Z., Efrizal, Aadrean, Resti Rahayu, Solfiyeni, Nurhaida, Roni Kurniawan, Fithria Diniyati dan Halimah Tus Sakdiah yang telah membantu terlaksananya kegiatan ini.

\section{DAFTAR PUSTAKA}

Dressler, R.L. 1981. The Orchids-Natural History and Classification. Harvard University Press, London England

Dressler, R.L. 1993. Phylogeny and Classification of The Orchid Family. Dioscorides Press, Oregon USA.

Griesbach, R.J. 2002. Development of Phalaenopsis Orchids for The Mass-Market. In trend in new crops and new uses. Janick, J. and A. Whipkey (eds.). ASHS Press, Vancouver USA.

Hani, A., T.W. Widyaningsih dan R.U. Damayanti. 2014. Potensi pengembangan jenisjenis tanaman anggrek dan obat-obatan di jalur wisata loop-trail CikanikiCitalahab Taman Nasional Gunung Halimun-Salak. Jurnal Ilmu Kehutanan 8(1): 42-49.

Kurniawan, F.Y., A. Setiaji, F. Putri, A. Suyoko, and E. Semiarti. 2018. Diversity and conservation strategy of orchids under anthropogenic influence in Taman Wisata Alam Curug Setawing, Yogyakarta. Pros. Sem. Nas. Masy. Biodiv. Indon 4(2): 173-177.

Lafreniere, D., V. Menuz, T. Hurlimann \& B. Godard. 2013. Knowledge dissemination interventions: A literature review. SAGE Open 3: 1-14.

Pillon, Y. and M.W. Chase. 2007. Taxonomic exaggeration and its effects on orchid conservation. Conservation Biology. 21(1): 263-265.

Rahman, D.F. dan Juraemi. 2008. Analisis finansial budidaya anggrek Dendrobium (Studi kasus di UPTD Balai Benih Induk Hortikultura Loa Janan). EPP 5(2): 1217.

Santosa, A. 2006. Prospek Agribisnis Berbasis Tanaman Hias Usaha Bunga Sedap Malam dan Anggrek Vanda Douglas. Caraka Tani XXI(1): 1-8.

Sutiyoso, Y. 2002. Peluang Bisnis Anggrek. Penebar Swadaya, Jakarta. 